\title{
Exploring Married Malay Couples' Conceptions of a Satisfying Marriage: Some Implications for the Education of Family Counsellors
}

\author{
Rozaina Zainul Abidin \\ Kulliyyah of Education, \\ International Islamic University Malaysia, \\ Kuala Lumpur, Malaysia \\ rozainazainul@gmail.com
}

\begin{abstract}
The objective of this study was to understand the phenomenon of a satisfying marriage among Malay married couples in Malaysia. It is submitted that a happy marriage starts from the feeling of satisfaction felt by married couples. However, with the rising statistics of marital problems and divorce cases reported in Malaysia, the phenomenon of satisfaction among married couples, the factors that contribute to it, as well as the challenges and ways to overcome them, need to be understood. The research employed a qualitative phenomenological method of enquiry. Two married couples, consisting of two males and two females, were selected as participants for indepth one-on-one interviews. They were of different couple profiles, age groups and lengths of marriage that fit into the intended selection criteria. In this study, a satisfying marriage was described through the feelings of peace, tranquillity and calmness, the happiness of family members, the positive feelings felt from the presence of family, the sense of togetherness, strength and support as well as the grateful feeling of having a spouse with commendable attributes. With regard to the factors that contribute to marital satisfaction, four major themes and eight subthemes were identified. The four major themes were "Attitudes and Actions of Spouse", "Relationship with Others", "Finance and Career" and "Religion". The subthemes that emerged from "Attitudes and Actions of Spouse" included "Complementary Roles", "Respect and Tolerance", "Physical Intimacy, Bonding and Fulfilment", "Understanding and Trust", "Communication," and "Humor." Meanwhile, the subthemes that emerged from "Relationship with Others" were "Relationship with Children" and "Relationship with In-Laws and Relatives." Two major themes emerged in regard to the challenges in achieving a satisfying marriage, which were "Attitude of Couples" and "External Factors." There are three main highlights in the findings of this study, namely "peace" as an important element in a satisfying marriage, the role of religion in a satisfying marriage, and the existence of gender differences in needs and expectations in a marriage. This study is hoped to be a significant endeavor in creating an awareness on the subject of marital satisfaction in Malaysia. It has implications for education, marriage and family counselling, as well as personal growth, and could serve as a basis for further efforts to promote a more satisfying marital institution.
\end{abstract}

Keywords: Marital satisfaction, satisfying marriage, marital institution, phenomenology, family counselling 


\section{INTRODUCTION}

Marriage is a commitment made by a couple where the spousal relationship leads to the development of a family institution. It is submitted that a satisfying marriage is important in building a stable and fully functioning family institution in any society. From the emotion perspective, marital satisfaction is described as the state of being contented, either with the interaction, experiences or expectations of a marriage (Ward, Lundberg, Zabriskie, \& Berrett, 2009). However, other scholars argue that simply associating positive emotions within the marital experiences does not guarantee the contentment with marriage and with the spouse (Bradbury, Fincham \& Beach, 2000). According to the social exchange perspective, marital satisfaction is defined as a reflection of the perceived benefits and costs by spouses in a marriage (Stone \& Shackelford, 2006). In other words, the greater the benefits a person perceives to experience in the marriage, the more satisfied he or she is with the marriage and spouse, and vice versa. The theory does not only describe marriage satisfaction in terms of the rewards and cost exchange, but also the reciprocal behaviours of the spouses (Nakonezny \& Denton, 2008).

\section{Factors Affecting Marital Satisfaction}

Literature has attempted to explore the factors that contribute to a satisfying marriage; however, a qualitative understanding on the subject matter is found to be limited. Inconsistencies in current findings may be brought about by the differences in marriage contexts. For instance, from the Pakistani women's perspective, Fatima and Ajmal (2012) have identified sixteen themes, which include 'Similarities of Religious Sects', 'Satisfaction', 'Compromise', 'Love', 'Care', 'Trust and Understanding', 'Communication', 'Age Differences', 'Sincerity and Respect', 'Sharing', 'Forgiveness', 'Spouse Temperament', 'Strength through Children', 'Family Structure', 'Education and Status' and 'Positive Relations with In-Laws,' as the contributing factors.

In an attempt to develop a marital satisfaction model, Madanian and Mansor (2011) found that some contributing dimensions of marital satisfaction among Iranian couples in Malaysia include children's issues, conflict resolution, time together, financial issues, personality traits, communication, family of origin, commitment, support and sexual relationship. In another study involving Iranian female students in Malaysia, the themes of 'Financial Issues', 'Intimacy', 'Commitment' and 'Children Education' were identified (Madanian, Mansor \& Omar, 2013). According to Indian Muslim women in Malaysia, nine factor and 19 sub-factors enhance their marital satisfaction, namely 'Marital Expectations', 'In-Laws Involvement', 'Housekeeping', Division of Tasks and Decisions', 'Foundations of Happiness', 'Social Factors', Religious Factors', 'Communication', 'Companionship', 'Unconditional Acceptance' and 'Support' (Arshad, 2018).

While it is acknowledged that a satisfying marriage is important in building a stable family institution in any society, unfortunately the rising statistics of marital problems and divorce cases as shown in the Malaysian Quality of Life Report 2011 and data by Syariah Judiciary Department of Malaysia indicate that the current approach in working towards the 
above objective is not working as effectively as it should. Not only that the divorce rates in Malaysia have increased more than double from 2004 to 2012, but the fact that the highest divorce cases within the similar period were recorded among couples that were only briefly married, i.e., between of 1 to 6 years (Harun, Ibrahim, \& Ladjana, 2014), also suggested that even newlywed couples face serious issues in coping with the challenges and dissatisfaction in sustaining a marriage.

Although an abundance of studies exists on the subject of coping, empirical understanding on the views of marital satisfaction in the local context is found to be limited. Hence, before a bolder and pragmatic approach is proposed towards building and promoting more satisfying marriages among the Malays who are the majority segment in Malaysia, there is a need to understand this subject matter and what contributes to the satisfaction in their marriages.

\section{Research Objectives}

Given the preceding concerns as discussed, this study attempts to understand the phenomenon of marital satisfaction among married Malay individuals in Malaysia by studying their interpretations and conceptions of what constitutes a satisfying marriage, the factors that contribute to it, the challenges that they face as well as ways to overcome those challenges towards achieving a satisfying marriage.

\section{Theoretical Framework}

The theoretical reference underpinning this study is drawn from the Social Exchange Theory which explains the factors that drive satisfaction in a relationship. The theory was introduced in 1958 by the sociologist George Homans who defined social exchange as the exchange of activity, tangible or intangible, and more or less rewarding or costly, between at least two persons (Lawler, 2001). It assumes that rewards and costs drive relationship satisfaction and decisions. In a marital relationship, both the husband and wife take responsibility for one another and depend on each other. The theory explains that the first element of the relationship includes the 'Costs' which are the elements that have a negative value to a person, such as the effort, time or money being put into a relationship and the negative attributes of a partner. The second elements are 'Rewards' which are the elements of a relationship that have positive values such as a sense of acceptance, support and companionship. The theory submits that people calculate the overall worth of a particular relationship by subtracting its costs from the rewards it provides, thus explaining the satisfaction that a spouse achieves when he or she feels that the other party is beneficial to him or her in any way. Figure 1.1 illustrates the proposed conceptual model.

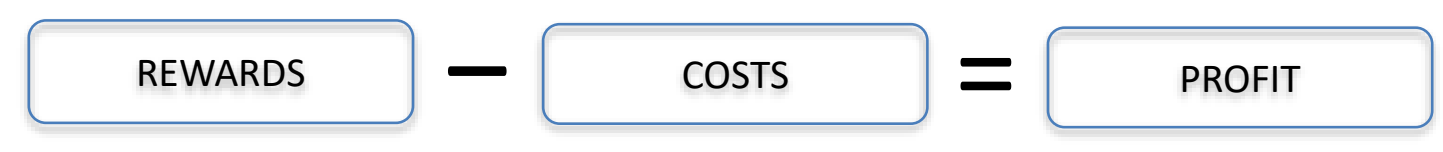

Figure 1: Social Exchange Theory (Homans, 1958) 
In other words, the theory explains that the worth of a marital relationship influences its outcome. In a mutually beneficial exchange, each spouse supplies the needs and wants of the other party at a lower cost to self than the value of the resources the other party provides.

\section{METHODOLOGY}

\section{Research Design}

This study is a qualitative undertaking using the phenomenological approach. Face to face interviews were conducted using the open ended semi-structured interview method to examine the phenomenon of marital satisfaction among married Malay couples in Malaysia. It is phenomenological because it uncovers the lived experiences of these couples in regard to married life and the ensuing satisfaction or dissatisfaction, as well as the factors leading to it.

\section{Participants}

Four married participants from two married couples were recruited through purposeful selection for the in-depth one-on-one interviews. They were of different couple profiles, age groups and lengths of marriage that fit into the intended selection criteria and provide different couple dynamics and insights into this study. Couple 1 had been married for 36 years, representing the marriage length bracket of more than 20 years, and resided outside of Klang Valley (i.e., in Kuala Terengganu, specifically). They had grown up children who were already married and grandchildren. The husband used to hold a high-ranking position in the corporate and business world, while the wife was of a lower academic and socio-economic background and worked as a full-time housewife. When they got married, the husband (M1) was a bachelor, while the wife (F1) was a divorcee with two kids, bringing the elements of a blended family into the perspective. On the other hand, participants from Couple 2 were younger and fell within the bracket of 10 to 20 years of marriage. They resided in Klang Valley. Both were highly educated, and held high profile positions in their own fields. They represented a busy working couple from a dual-income family, who are juggling between work and career demands and raising small children.

\section{Data Collection: Interview Sessions and Interview Protocol}

The data were collected between March 2016 to September 2017 at the venues and dates chosen by the participants in four separate individual interview sessions. The interviews with the couples were conducted separately from their spouses to enable them to express their views freely and honestly. When the researcher met with them, they were briefed about participants' informed consent, which included information about the study's purpose, their rights to withdraw from the study at any time, and procedures for data collection. The consent form also addressed issues of confidentiality and potential risks and benefits involved with their participation. 
Then the researcher proceeded with the rest of the interview protocol which started with the participants describing themselves and their spouses. Next, they were asked to describe their conceptions of a satisfying marriage, the factors they perceived to contribute to their marital satisfaction, followed by challenges that would impede the achievement of a satisfying marriage as well as ways and means to overcome them.

On average, the four one-on-one interviews took about one hour each; they were all audiotaped and transcribed verbatim. The interviews were conducted in Malay and translated into English after verbatim transcription. The field notes were completed immediately after each interview to allow an immediate reflection on the input given by the participants. Next, the transcripts and reflective comments were formed as the raw data. Pseudonyms were ascribed to each participant to protect their identities and ensure confidentiality. The transcripts were then coded and analyzed for emergent themes and subthemes in an inductive process.

\section{Data Analysis}

Data analysis was conducted in four stages, starting from the transcriptions of the recorded interview sessions to written protocols. Secondly, the identification of statements, phrases or words that were useful to explain the phenomenon was done. Next, the statements were grouped into various themes that had been identified. One general statement per theme was written next to all the statements in order to capture the essence of each theme. During this process, some of the statements were being further grouped and thus, a few subthemes emerged within the themes. The next step involved analyzing the themes and subthemes that were identified before an explanation about the phenomenon studied was formed based on the data.

\section{FINDINGS}

\section{The Meaning of a Satisfying Marriage}

The participants described a satisfying marriage in many different ways, quoting various examples and life situations. A satisfying marriage was described with an identification with the feelings of peace, tranquility and calmness, the happiness of family members, the positive feelings felt from the presence of family, the sense of togetherness, strength and support as well as the grateful feeling of having a spouse with commendable attributes.

\section{Contributing Elements of a Satisfying Marriage}

Four major themes and eight subthemes emerged in the analysis of the data. The four major themes were 'Attitudes and Actions of Spouse', 'Relationship with Others', 'Finance and Career' and 'Religion'. Subthemes that emerged from 'Attitudes and Actions of Spouse' included 'Complementary Roles', 'Respect and Tolerance', 'Physical Intimacy, Bonding and Fulfillment', 'Understanding and Trust', 'Communication' and 'Humor'. Meanwhile, 
subthemes that emerged from 'Relationship with Others' are 'Relationship with Children' as well as 'Relationship with In Laws and Relatives'.

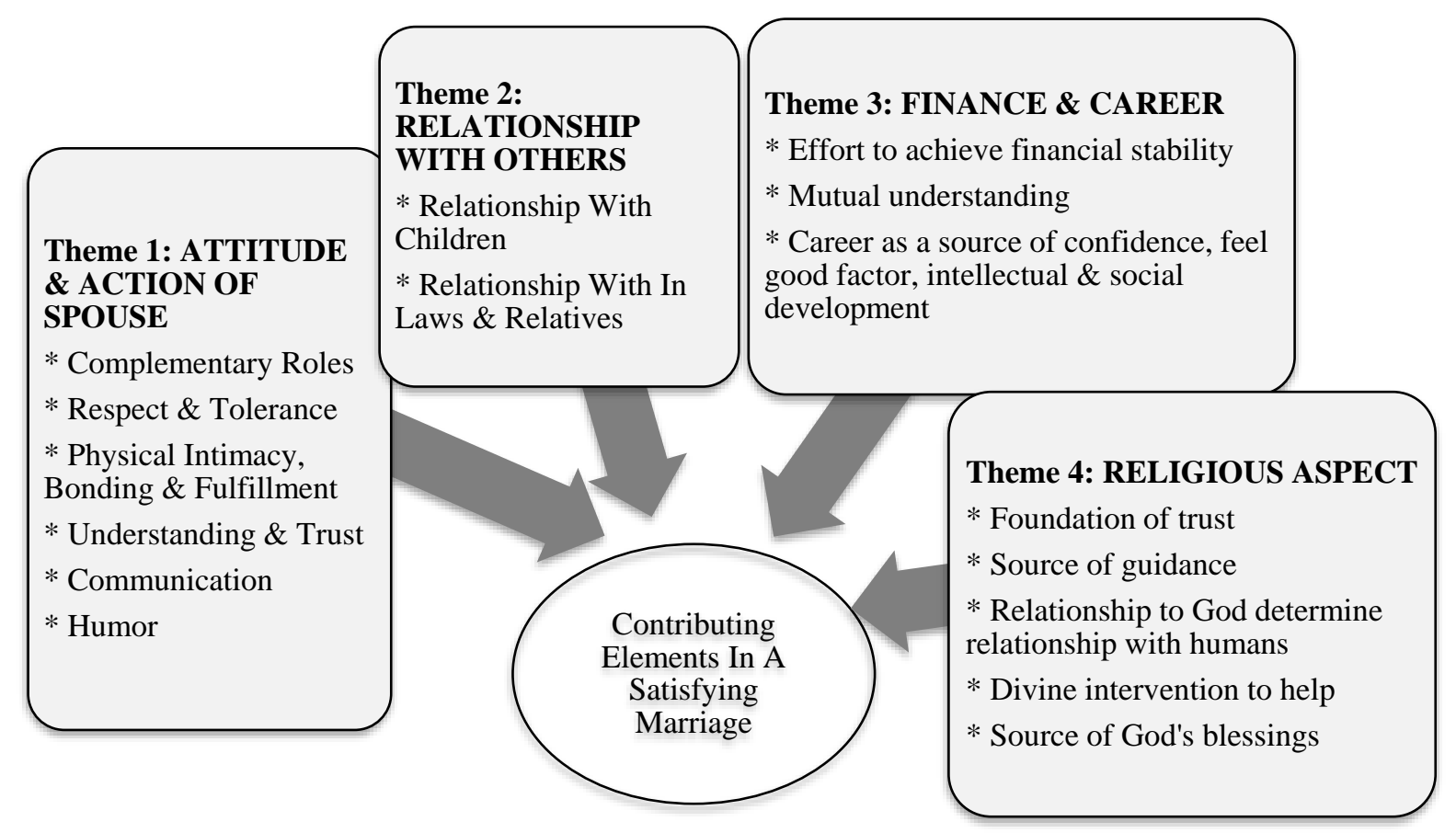

Figure 2: The elements of a Satisfying Marriage: The Emergent Themes

\section{Theme 1: Attitude and Actions of Spouse}

Six distinct subthemes emerged under 'Attitudes and Actions of Spouse', which include 'Complementary Roles', 'Respect and Tolerance', 'Physical Intimacy, Bonding and Fulfilment and Intimacy', 'Understanding and Trust', 'Communication' and 'Humor'.

\section{Complementary Roles}

The different roles played by a husband and a wife were seen to fulfil the needs and gaps of each other and thus, driving the spousal satisfaction. While their husbands described the female participants as good nurturers and caretakers, the male participants on the other hand, were described as good leaders, role models and providers for the family.

"I think, it's how she took care of me. The way she took care of my food and drinks... MasyaAllah. There was no gap at all." (M1)

"He set a good example of a leader in a family. He set the basic rules. For example, the discipline for solat, for reading and memorization of Al-Quran., respecting the elderly, there are manners. I learn a lot from him. And he set a good example as well. All the rules he set, he himself practices it." (F2)

\section{Respect and Tolerance}

The account on 'Respect and Tolerance' as shared by the female participants, suggests the quality of obedience towards their husbands, which brings much contentment in the marriage resulting in the feeling of marital satisfaction. 
"Love and respect. Meaning that, love alone is not sufficient. Each of us must respect our partner. Respect his differences, his limitations, his opinions which somehow always different from us, because somehow, we come from different backgrounds, upbringing, having different values. Respect is important. Respect must be gained. That the husband with his leadership, with his values, has gained respect from the wife, the children, from everybody." (F2)

\section{Physical Bonding, Connectedness and Fulfilment}

The participants described "physical bonding, connectedness and fulfilment" in a few ways. Firstly, it refers to the act of physical affection or romantic bonding.

“(I) want to feel that I am loved. That there's someone next to us. Even if he is far, I want him to remember me often, and give me a call. But if we get an unromantic husband, we have to initiate the emotional bonding." (F2)

It was also mentioned in the context of the wife's obedience towards her husband, and this act was seen as important in keeping her husband contented in their marriage.

"You need to strive to meet your husband's requests although sometimes you are just physically exhausted. If you fail to fulfil his needs, he may feel hurt. So even though you are tired, you simply have to try and make him happy." (F1)

The third aspect was related to the element of "variety" in physical bonding and intimacy.

"The physical intimacy and bonding are very important. And you need to have varieties in the marriage to keep it alive and interesting. For example, you could take your spouse outside of your town or city once in a while...staying in the same place for a long time sometimes dampens the relationship, so you need to do something new....it's something to be excited about that makes the bonding stronger...." (M1)

\section{Understanding and Trust}

'Understanding and Trust' refers to the ability of a spouse to understand the needs or feelings of the other party and to believe in his/her qualities, reliability or strengths. While 'Respect and Tolerance' were noted as important in the discussion with the female participants, the male participants on the other hand, talked about 'Understanding and Trust' as important attributes of their wives.

"Most importantly, she understands my needs. She is so understanding. In English, it's called emotional intelligence. She knows when she can talk to me, what she needs to talk about. She is smart in managing her emotions. " (M1)

\section{Communication}

Open communication was mentioned as a vital element in their marriage, especially during crisis and challenges. 
"We discussed--we cannot make assumptions. Everything is communicated. Kadang-kadang (sometimes) if we need to discuss something, we talk in a private session, we take it outside, over dinner or lunch or a private session together. It is not very structured. We don't have a periodic arrangement, it depends. Daily communication also depends on time. We prefer face to face." (M2)

\section{Humor}

Humor refers to the quality of being amusing or entertaining as displayed by a spouse towards his/her partner.

Firstly, as I have mentioned, it's about sleeping. Since I got married until now, we never sleep separately, always slept in the same bed. Secondly, do not eat on your own when you are at home. Whatever it is, always be together. Thirdly, bathe together once a week. Rasulullah himself, would bathe from the same basin with his wife once in a while. Fourthly, cracking jokes, it always has to be there." (M1)

\section{Theme 2: Relationship with Others}

This theme refers to the inter-personal relationships forged with significant others and the role played by those significant others that could impact the level of satisfaction between the couple. Two distinct sub-themes emerged, namely "Relationship with children" and "Relationship with in laws and relatives."

\section{Relationship with Children}

The female participants shared positive feelings they had regarding the presence of children in their respective marriages.

"Kids always gave us support." (F1)

"(Kids) tie our love together. In any circumstances, kids would be able to melt his (husband's) heart." (F2)

On the other hand, the male participants expressed their satisfaction for having children to complete their family and complimented their wives for being able to raise and manage their children well.

"When you feel that they are taken care of, they are happy, they are healthy, you know that all aspects of their life are well taken care of by your spouse." (M2)

\section{Relationship with In-Laws and Relatives}

Other family members such as relatives and in-laws were discussed in close relation to the proactive role played by the husbands and wives in treating and managing them.

"When she is good at pleasing her mother and father-in-law, her mother-in-law would be very happy with her. When the parents are happy, the wife is happy, no husband would not be happy with it." (M1) 
Clearly, based on this testimony, making the in-laws happy is an important element of marital satisfaction.

\section{Theme 3: Finance and Career}

Issues related to finance and career in a marriage include maintaining financial stability, managing family finances, and pursuing career aspirations.

\section{Efforts and Skills to Achieve Financial Stability}

The couples shared their experience regarding their efforts and skills in managing their financial affairs, especially in the early part of their marriage.

“Alhamdulillah, now we don't have any financial difficulties (now), but in the first few years of marriage, trying to stabilize, when we were studying. But it's the mutual understanding that you've developed." (M2)

As their marriage progressed over the years, the couple developed a mutual understanding of how they should manage their finances. The understanding has prevented a lot of disagreements with regards to financial management, hence contributing to overall marital harmony and contentment.

\section{Mutual Understanding on Managing Family Finances}

The ability to manage and maintain financial stability was achieved and developed through trust and mutual understanding between the husband and wife.

"In our case, there's no fixed monthly nafkah ke...it's based on understanding and trust. Of course, my wife is not calculative on that aspect..." (M2)

Spousal understanding and a give-and-take attitude have helped to build harmony and satisfaction in their marriage.

\section{Choice to Pursue Career Aspirations}

Although career was mentioned as a significant contributor to a satisfying marriage, role prioritisation was more critical in maintaining it.

"Yes, [career is important because through it] I gain confidence about myself. I feel good about myself. (But) it should not jeopardise the family. (Meaning) it cannot come in conflict with your role as a wife. Career always comes second. But he never asked me to resign. I think he is more satisfied when I am working because I can keep pace with his intellectual progress, more updated. He can treat me as a friend. He doesn't just need a wife, but also a friend. " (F2)

Having a career is deemed important as it helps the spouse to maintain a certain level of intellectuality in the relationship, which keeps the marriage alive. The ability to connect intellectually is an important factor for marital satisfaction, according to F2. 


\section{Theme 4: Religious Aspect}

"Religion is the most important aspect. All the things that we have spoken basically relate to the fundamentals. For example, when we talk about trust, religion is the bedrock of the whole thing. The foundation is definitely the religion. In the case of marriage, whatever love and affection towards your partner must be based on the love and affection to Allah. We choose a wife because of Allah. And He is the only one who can maintain the feelings. It means that our relationship with Allah also play an important role. It is a kind of two-level relationship, your relationship with Allah and your relationship with your partner." (M2)

According to M2, religion plays a fundamental role in influencing satisfaction in his marriage as it determines the purpose and all the actions that follow through in the whole journey of marital relationship.

\section{Challenges in Achieving A Satisfying Marriage}

Two major themes emerge with reference to the challenges in achieving a satisfying marriage, which include 'Attitude of Couples' and 'External Factors'. 'Attitude and Actions of Couples' refers to the mindset or way of thinking, feeling and behaving of a spouse in a marriage that could detriment and dampen the couple's relationship such as the lack of love, lack of attention and effort in nurturing the relationship, lack of commitment towards religious teachings, and hot temperedness. Meanwhile 'External Factors' refers to the influences outside the marriage or family such as in-laws, family members, third party seduction, and work-related issues that could pose challenges or obstacles for married couples in achieving marital satisfaction.

\section{Theme 1: Attitude and Actions of Spouse}

Spousal attitude and actions were reiterated by the participants as an element that makes or breaks a marriage.

"The challenge is when there is lack of love being expressed. When it is gone, gaps will be formed, though it might be small. A man who looks for it in his wife but he is not able to find it in her, will start to look for it in other women, and what if she has it?" (M1)

Lack of love expression was mentioned as the critical point that could create a gap in the spousal relationship.

\section{Theme 2: External Factors}

External influences such as in-laws, family members, third party seduction and work-related issues pose challenges or obstacles in achieving marital satisfaction.

\section{In laws and family members}

F1 shared how she faced and managed the negative perceptions and remarks from her parents and sisters-in-law at the beginning of her marriage, especially due to the cultural stereotype of a single mother being married to a bachelor husband. 
"The challenges come from the sisters-in-law and family members." (F1)

\section{Third party seduction}

M2 talked about the threats coming from third parties who tried to seduce her spouse despite his being married, and how he managed such a situation. Failure to handle such threats intelligently could put the marriage on the rocks.

"So far from what I observe, many people have played a role trying to 'menggoda' (seduce) you." (M2)

\section{Work-related challenges}

Work and career issues such as the struggle of balancing work and family lives, communication issue and the challenge of being cheated by others have added stress and tension to the couples.

"It's about challenges at work, we were cheated by so many people (which has affected us)." (F1)

\section{Ways of Overcoming the Challenges in a Marriage}

Different ways were adopted by the participants in overcoming their marital challenges. They include adopting good communication skills such as private discussion ("If we need to discuss something, we talk in a private session."), setting clear life objectives and staying focus ("You have to understand the objective of life, what do you want to achieve in life, you know the roles and responsibilities that you are undertaking"), being appreciative and always compliment the spouse ("Compliment her. We have to praise her repeatedly"), practising certain religious rituals when facing marital issues ("Make doa. Ask from Allah. Be grateful"), managing personal stress level ("But it is how we manage stress. We talked about it. We managed some of them."), continue seeking knowledge ("Gain knowledge, read books. From there, we will be able to manage our emotions"), and lastly seeking support from others ("We have an outlet. Like my mother, friends, with Allah.)

\section{Highlights of the Findings}

The present study discovers three important highlights in the findings: (1) "Peace" is an important element in a satisfying marriage; (2) Religion and religiosity are crucial to the development of tolerance, peace and harmony that build a satisfying marriage; and (3) Gender differences in spousal needs and expectations in a marriage must be well-understood and addressed.

\section{The Element of 'Peace' in a Satisfying Marriage}

The word 'peace' in the context of a satisfying marital experience was described in different ways. Firstly, 'happiness' in marriage was described through a few words related to 'Peace' such as 'aman', 'tenteram', 'tenang', 'senang' ('peace', 'tranquillity', 'calmness' and 'pleased'). 'Peace and tranquillity' were also mentioned in the context of the comfortable feeling felt by a spouse when seeing that the family is happy, the positive feelings attained from the presence of family members as well as the sense of togetherness, strength and support 
gained out of a satisfying marriage. This finding shows that not only is the element of 'peace' significant in building a satisfying marriage, but it is also something which could be felt, interpreted and defined differently by different individuals. From the perspective of existentialism, all individuals are believed to have their own meaning, values, assumptions and expectations towards a particular concept or subject matter, and they should be encouraged to explore their own perspectives before they can take ownership of them.

Next, it can also be deduced that the concept of 'peace' is wholesome and not an individualistic concept. It was expressed in relation to the feeling that was attained as a result of the relationship with other entities, specifically with family members and God. In Islam, this concept is explained as "habluminallah-habluminannas" (relationship with Allah- relationship with humans) which propagates that it is a necessity for all Muslims to have a balanced and harmonious relationship with the Divine Being (a vertical relationship) and also with other human beings (a horizontal relationship) in order to achieve God's blessing. Thus, the different experiences of 'peace' described by the participants may serve as the consequence of their good relationship that they have established with God as well as with others, which then, would contribute to their feelings of satisfaction.

Additionally, this finding is also in line with the Islamic perspective with regard to the objective of a marriage and that Allah has created men and women as a company for each other so they can live in peace and tranquillity according to the way of life as commanded by Allah and His messenger:

"And among His signs is this, that He created for you mates from among yourselves, that you may dwell in peace and tranquillity with them, and He has put love and mercy between your (hearts): Verily in that are signs for those who reflect."

(Al Quran, 30: 21)

\section{The Role of Religion in a Satisfying Marriage}

This study provides a new insight into how 'God and religion' play a significant role in various aspects of a marriage. Firstly, it is believed that the quality of spousal relationship is related to the quality of their relationship with God. Building on the model of 'habluminallah, habluminannas' concept in Islam, it is proposed that to achieve a satisfying marriage, married couples should improve their relationship with God because if both husband and wife work to be closer to God, they can also grow closer to each other.

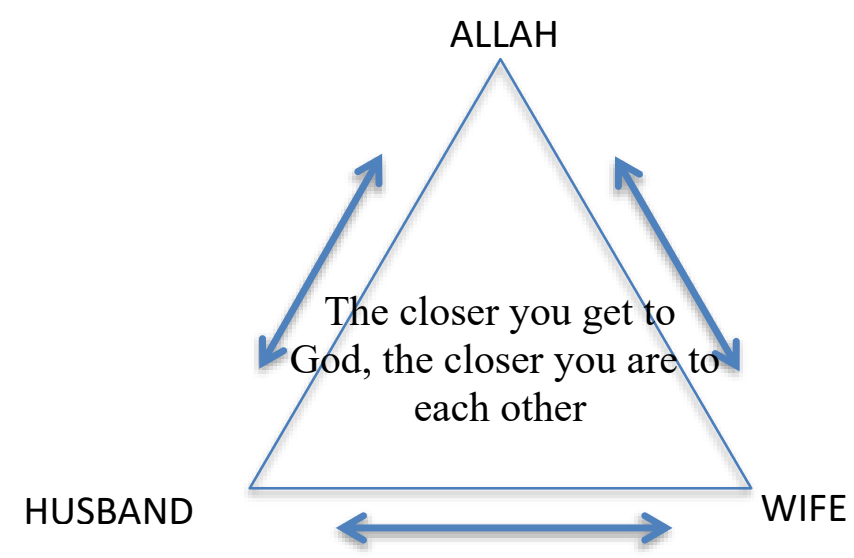

Figure 3: The Concept of Habluminallah, Habluminannas in Achieving a Satisfying Marriage 
Secondly, 'religion' serves as a foundation and source of guidance and governance in marriage on which trust and commitment are built between the husband and wife. Islam has also underlined the premise that all human beings are to be tested in this world to assess their obedience to the Almighty God before they could be rewarded with the ultimate happiness in the hereafter, thus marriage is also viewed as a platform for Muslims to seek God's blessings and to attain the ultimate happiness in the hereafter. With that, married couples would then be able to endure and persevere through all the challenges and obstacles that they face in their marriage because the goal is not just to seek happiness in this temporary world, but most importantly, in the hereafter which is eternal.

"Verily, We shall put you to test with some fear, and hunger, and with some loss of wealth, lives, and offspring. And (O Muhammad) convey good tidings to those who are patient, who say, when inflicted by hardship, "Verily we are of God and verily to Him shall we return;" upon them is the blessings of Allah and His mercy."

(Al Quran, 2:155)

Finally, religion does not only serve as a coping strategy in helping the married couples to cope and manage their emotions, but Divine intervention is sought after as the ultimate avenue for seeking help to solve the marital issues at hand.

\section{Gender Differences in the Expression of Needs and Expectations in a Marriage}

There are some noticeable differences in responses between genders in this study. In discussing the theme of complementary roles, the male participants have described 'good nurturers and caretakers' as important qualities that they seek in their wives, while the female participants mentioned the roles of 'good leaders, role models and providers' in their 'satisfying' husbands. Besides that, 'respect and tolerance' are noted as important to the female participants, while the male participants talked about 'understanding and trust' as the important attributes of their wives.

Additionally, the male and female participants also described 'physical intimacy and fulfilment' differently. The female participants were observed to be more illustrative in narrating their intimate experiences during the interviews, especially with regard to the element of affection and romance between them and their husbands, which include non-verbal physical affection such as hugging, caressing and giving presents as well as the verbal expression such as saying "I love you". This result is similar to what was observed by Madanian, Mansor and Omar (2013) in which the Iranian wives explained a feeling of insecurity if they did not get the intimate expressions from their husbands.

On the other hand, the male participants were observed to view this subject matter in a slightly different light. Not only are physical intimacy and fulfilment being discussed in the context of the sexual activity itself, it is also noted that men are more appreciative towards the element of 'variety' in their relationship with their wives.

Such findings indicate the differences of needs and expectations in a marriage between men and women. The study also identifies 'communication' as an important contributing factor in a satisfying marriage. If married couples fail to communicate and manage their feelings, 
problems and expectations, their relationship may be affected and the possibility of misunderstanding between them is greater.

\section{DISCUSSION}

Different and unique interpretations were used to illustrate what a satisfying marriage meant to the participants. Although similar words were used, such as 'tenang' (peace) and 'bahagia' (happiness), their interpretations and illustrations of these concepts were different from one to another, suggesting that counsellors could adopt the existentialist approach in conducting marriage counselling, as couples should be encouraged to explore and express their own conceptions, meanings and ideals of a satisfying marriage to help them understand themselves better and realize how the husband and wife could be viewing these ideas differently.

Secondly, the research also indicated clearly that a satisfying marital relationship did not simply pop up. All the participants have put a lot of hard work and effort in striving to achieve success in their marriage. Thus, a satisfying marital relationship is the evolving result of hard work, effort, understanding and tolerance.

Thirdly, it is learned that 'attitude' is an important factor in making or breaking a marriage. Positive attitudes such as respect, tolerance, understanding, trust and teamwork in playing complementary roles to their spouse were the common denominator among the participants that had greatly influenced their satisfaction in marriage. Thus, a counsellor could assist married couples who are in conflict to acknowledge their differences, be more acceptance of spousal differences, explore ways and means of managing their issues, and work to complement each other. This points out the importance of communication skills and approaches that need to be acquired and learned by all married couples, regardless of whether they are in conflict or not. The counsellor, being someone fair and neutral to the clients, should play multiple roles such as being a mediator and a coach to his/her clients. Hence, it is critical for all family and marriage counsellors to be equipped with the necessary skills, especially the arts of negotiation and communication skills to not just handle family and marriage cases effectively, but also to model and coach their clients on how to negotiate and communicate with each other once the counselling process is terminated.

Next, 'physical intimacy, bonding and fulfilment' which were deemed to be important factors by the participants in driving their marital satisfaction, need to be given more attention to by counselling and health practitioners in terms of the awareness, knowledge and skills related to it. If this topic is still seen as 'taboo,' especially in the context of the Malay society, many married couples would still be shy in being open to discuss or learn about it, even if they have issues or unmet needs related to it.

Finally, it is learned that 'religion and strong faith in God' are regarded as a foundation, guiding principles and important coping strategies among the satisfied marriage couples in this study. When they were being tested with various issues and challenges throughout their married lives, they turned to God for guidance and relief. Various religious rituals such as 'muhasabah' (self-introspection), 'solat' and 'doa' (prayers and supplication to Allah) as well as 'zikir' 
(religious chant in the remembrance of Allah) were employed as effective coping methods to deal with or recover from any negative emotions encountered during any conflicts or tensed periods in their marriage.

\section{Educational Implications}

The findings brought to the fore some important educational implications in several aspects, the first of which concerns the education of competent family counsellors. It is proposed that a certificate or a post-degree program should be offered to all counselling practitioners and social workers to equip them with the necessary knowledge such as that concerning sex education and skills for conflict resolution and effective communication, as well as family counselling techniques before they are allowed to practice and manage any counselling cases in the field.

Counselling education should also incorporate creative strategies to equip counselling students with the necessary knowledge and skills in their preparation to manage different types of cases as well as the sophistication level of the clients. Courses on the integration of Islamic approaches into counselling practices should be incorporated in the training module for practising counsellors. Besides, religious coping as a huge source of empowerment or a buffer against various marital issues, other preventive and interventive strategies should be taught in counselling education to promote a more holistic approach, integrating the psychologicalbehavioural and spiritual approaches in family counselling.

As the subjects related to marital relationship are still regarded as taboo to be discussed openly among the Malay society (Manaf, Razak, Harries, \& Clare, 2011; Nor, Karim \& Ahmad, 2017), the study proposes the needs to consider incorporating sex education, emotional intelligence, communication and people skills in the school curriculum and expose the students early to the related subjects. It is important that family studies be emphasized as important subjects in the education system.

\section{CONCLUSION}

This study is significant in creating the awareness on the subject of marital satisfaction, especially in the context of Asian and Muslim married lives. It has implications for education, marriage and family counselling, as well as for personal growth, and could serve as a basis for further efforts to promote more satisfying marital institutions. Besides the strong emphasis on 'peace' as a significant element in the description of marital satisfaction, gender differences and the importance of religion in building a satisfying marriage were discovered. Additionally, the different insights, needs or expressions between the male and female participants with regard to three specific issues, i.e., "physical intimacy and fulfilment," "respect and tolerance," and "understanding and trust", as well as the importance of religion as a coping strategy in marriage were also some unique discoveries in this research. 


\section{REFERENCES}

Ali, A. (2001). Al-Qur'an. Princeton University Press.

Arshad (2018). Predicting Marital Satisfaction among Indian Muslim Women: A Phenomenological Study. American Journal of Humanities and Social Sciences Research, 4(11), 114-123.

Askari, M., Noah, S., Hassan, S. A. and Baba, M. (2012). Comparison the effects of communication and conflict resolution skills training on marital satisfaction. International Journal of Psychological Studies, 4 (1), 182-195.

Azahari, R. (2008). Factors contribute to marital problems among Malay Muslim women: a case study in Malaysia. Jurnal Syariah, 16 (2), 245-268.

Bradbury, T. N., Fincham, F. D., \& Beach, S. R. (2000). Research on the nature and determinants of marital satisfaction: A decade in review. Journal of Marriage and Family, 62(4), 964-980.

Carlson, M. J. (2006). Family structure, father involvement and adolescent behavioral outcomes. Journal of Marriage and the Family, 68 (1), 137-154.

Chien, S. C. H. and Mustaffa, M. S. (2008). Divorce in Malaysia. Working paper at the Seminar Kaunseling Keluarga, 27 August 2008, Skudai, Universiti Teknologi Malaysia.

Creswell, J.W. (2009). Research Design: Qualitative, Quantitative, and Mixed Methods Approaches. 3rd Edition. Los Angeles: Sage Publications, Inc.

Department of Statistics Malaysia. (n.d.). Population \& Housing Census of Malaysia 2010. Retrieved April 3, 2018.

http://instatmy.org.my/index.php?option=com_content\&view=article\&id=55:populati on-a-housing-census-of-malaysia\&catid=16:past-events \& Itemid=4

Economic Planning Unit Malaysia. (n.d.). Malaysian Quality of Life 2011. Retrieved April 3, 2018. http://www.epu.gov.my/home

Fatima, M., \& Ajmal, M. A. (2012). Happy marriage: a qualitative study. Pakistan Journal of Social and Clinical Psychology, 9(2), 37-42.

Fatimah, P.L.R. (2012). Improvement on marital satisfaction by using quality approach. Journal of Social Sciences and Humanities, 7 (1), 133-148.

Harun, N., Ibrahim, H. and Ladjana, J. (2014, January 12). Seks Punca Cerai. MyMetro. Retrieved March 14, 2018.

http://www2.hmetro.com.my/myMetro/articles/Sekspuncacerai/Article/index_html 
Kaufman, G. \& Taniguchi, H. (2006). Gender and marital happiness in later life. Journal of Family Issues. 27 (6), 735-757.

Khajeddin, N. Riahi, F. Salehi, M. Izadi-Mazidi, S. (2010). Effects of life skills workshops on marital satisfaction. Iranian Journal of Psychiatry and Behavioral Sciences, 4 (42-6).

Lavner, J.A. and Bradbury, T.N. (2010). Patterns of change in marital satisfaction over the newlyweds years. Journal of Marriage and Family, 72, 1171-1187.

Lawler, Edward J. (2001). An Affect Theory of Social Exchange. American Journal of Sociology, 107 (2): 321-352.

Madanian, L. and Mansor, S. (2011). Developing a marital satisfaction model for Iranian couples. Journal of Edupres, 1, 9-14.

Madanian, L., Mansor, S. and Omar, A.H. (2013). Marital satisfaction of Iranian female students in Malaysia: a qualitative study. Journal of Social and Behavioral Sciences. 84, $987-993$.

Manaf, A., Razak, A., Harries, M., \& Clare, M. (2011). Understanding quality of marriage among Malays. International Journal of Humanities and Social Science, 1(4), 170-179.

Mirfardi, A., Edalati, A., \& Redzuan, M. (2010). Relationship between background factors and Female Marital Satisfaction. Journal of Social Sciences, 6 (3), 447-452.

Nakonezny, P. A., \& Denton, W. H. (2008). Marital relationships: A social exchange theory perspective. The American Journal of Family Therapy, 36(5), 402-412.

Nimtz, M. (2011) Satisfaction and contributing factors in satisfying long term marriage: A phenomenological study. Retrieved November 6, 2018. http://digitalcommons . liberty.edu/cgi/viewcontent.cgi?article=1496\&context=doctoral

Nor, A. M., Karim, D. N. F. M., \& Ahmad, N. (2017). From nasty to healthy divorce: A marriage and family therapy model for working effectively with divorcing Malay-Muslim couples. MOJPC: Malaysia Online Journal of Psychology \& Counselling, 1(1).

Stone, E. A., Shackelford, T. K., \& Buss, D. M. (2007). Sex ratio and Mate Preferences: A Cross-cultural Investigation. European Journal of Social Psychology, 37(2), 288-296.

Uusiautti, S, \& Maata, K. (2012). The Ability To Love - A virtue-based approach. British Journal of Educational Research, 2 (1): 1-19.

Ward, P. J., Lundberg, N. R., Zabriskie, R. B., \& Berrett, K. (2009). Measuring Marital Satisfaction: A comparison of the Revised Dyadic Adjustment Scale and the Satisfaction with Married Life Scale. Marriage \& Family Review, 45(4), 412-429. 